\title{
Mobile measurements of ship emissions in two harbour areas in Finland
}

\author{
L. Pirjola ${ }^{1,2}$, A. Pajunoja ${ }^{3,4}$, J. Walden ${ }^{5}$, J.-P. Jalkanen ${ }^{5}$, T. Rönkkö ${ }^{3}$, A. Kousa ${ }^{6}$, and T. Koskentalo ${ }^{6}$ \\ ${ }^{1}$ Department of Technology, Metropolia University of Applied Sciences, Helsinki, Finland \\ ${ }^{2}$ Department of Physics, University of Helsinki, Helsinki, Finland \\ ${ }^{3}$ Aerosol Physics Laboratory, Department of Physics, Tampere University of Technology, Tampere, Finland \\ ${ }^{4}$ Department of Applied Physics, University of Eastern Finland, Kuopio, Finland \\ ${ }^{5}$ Air Quality, Finnish Meteorological Institute, Helsinki, Finland \\ ${ }^{6}$ Helsinki Region Environmental Services Authority HSY, Helsinki, Finland
}

Correspondence to: L. Pirjola (liisa.pirjola@metropolia.fi)

Received: 4 May 2013 - Published in Atmos. Meas. Tech. Discuss.: 5 August 2013

Revised: 10 November 2013 - Accepted: 9 December 2013 - Published: 21 January 2014

\begin{abstract}
Four measurement campaigns were performed in two different environments - inside the harbour areas in the city centre of Helsinki, and along the narrow shipping channel near the city of Turku, Finland - using a mobile laboratory van during winter and summer conditions in 20102011. The characteristics of gaseous $\left(\mathrm{CO}, \mathrm{CO}_{2}, \mathrm{SO}_{2}, \mathrm{NO}\right.$, $\mathrm{NO}_{2}, \mathrm{NO}_{\mathrm{x}}$ ) and particulate (number and volume size distributions as well as $\mathrm{PM}_{2.5}$ ) emissions for 11 ships regularly operating on the Baltic Sea were studied to determine the emission parameters. The highest particle concentrations were $1.5 \times 10^{6}$ and $1.6 \times 10^{5} \mathrm{~cm}^{-3}$ in Helsinki and Turku, respectively, and the particle number size distributions had two modes. The dominating mode peaked at 20 $30 \mathrm{~nm}$, and the accumulation mode at $80-100 \mathrm{~nm}$. The majority of the particle mass was volatile, since after heating the sample to $265^{\circ} \mathrm{C}$, the particle volume of the studied ship decreased by around $70 \%$. The emission factors for $\mathrm{NO}_{\mathrm{x}}$ varied in the range of $25-100 \mathrm{~g}(\mathrm{~kg} \text { fuel })^{-1}$, for $\mathrm{SO}_{2}$ in the range of $2.5-17.0 \mathrm{~g}(\mathrm{~kg} \text { fuel })^{-1}$, for particle number in the range of $(0.32-2.26) \times 10^{16} \#(\mathrm{~kg} \text { fuel })^{-1}$, and for $\mathrm{PM}_{2.5}$ between $1.0-4.9 \mathrm{~g}(\mathrm{~kg} \text { fuel })^{-1}$. The ships equipped with SCR (selective catalytic reduction) had the lowest $\mathrm{NO}_{\mathrm{x}}$ emissions, whereas the ships with DWI (direct water injection) and HAMs (humid air motors) had the lowest $\mathrm{SO}_{2}$ emissions but the highest particulate emissions. For all ships, the averaged fuel sulphur contents (FSCs) were less than $1 \%$ (by mass) but none of them was below $0.1 \%$ which will be the new EU directive starting 1 January 2015 in the $\mathrm{SO}_{\mathrm{x}}$ emission control
\end{abstract}

areas; this indicates that ships operating on the Baltic Sea will face large challenges.

\section{Introduction}

Worldwide, more than $80 \%$ of trading goods are transported by ship (Fuglestvedt et al., 2009). Large ships are primarily powered by diesel propulsion systems and usually fuelled by heavy fuel oil (HFO). HFO is low-grade fuel that includes high concentration of impurities such as sulphur, ash, asphaltenes, and metals (Sinha et al., 2003). Marine distillate oils (MDO) are refined fuels, but due to their higher costs, they are generally only used for small, medium-speed diesel engines such as auxiliary engines for port activities, and for main engines when manoeuvring in harbour areas (Saxe and Larsen, 2004). Marine traffic is a significant source of diesel emissions, which affect global climate, air quality and human health. Emitted $\mathrm{CO}_{2}$ and ozone formed by $\mathrm{NO}_{\mathrm{x}}$ emissions are greenhouse gases whereas $\mathrm{SO}_{2}$ emissions cause cooling through effects on atmospheric particles and clouds. The present net effect is cooling (Fuglestvedt et al., 2009). Around two-thirds of ship emissions occur within $400 \mathrm{~km}$ of coastlines, leading to reduced air quality in coastal areas and harbours. Corbett et al. (2007) estimated that shippingrelated $\mathrm{PM}_{2.5}$ emissions are responsible for approximately 60000 premature cardiopulmonary and lung cancer deaths annually at a global scale. 
Shipping emits both primary and secondary particles. Incomplete combustion of carbon produces primary soot particles. Besides organic carbon, elemental carbon and ash, these particles also include vanadium, nickel and sulphur due to impurities in HFO. Fuel sulphur is oxidised to $\mathrm{SO}_{2}$ and further to $\mathrm{SO}_{3}$ during combustion. The amount of $\mathrm{SO}_{3}$ depends on the combustion temperature, but the reaction is catalysed by the presence of vanadium (Isakson et al., 2001). During dilution and cooling, $\mathrm{SO}_{3}$ reacts with water vapour, forming sulphuric acid which subsequently can nucleate to form secondary particles and/or condense onto pre-existing particles (Arnold et al., 2006). Nanoparticle emissions depend on the technology parameters: fuel, after-treatment system used, and operating conditions, e.g. engine load, ship's speed and acceleration. Eyring et al. (2005) and Fridell et al. (2008) have reported that a selective catalytic reduction (SCR) is able to significantly reduce the emissions of marine diesel engines; for example, particle mass emissions by $50 \%$ over the whole size range, and for full load the mass emissions of $\mathrm{NO}_{\mathrm{x}}$ by $90-99 \%$, $\mathrm{HC}$ and $\mathrm{CO}$ by $80-90 \%$, and soot by $30-50 \%$. Different scrubbing systems have been commonly applied to diesel power plants on land, but until now their commercial installation on ships has been scarce (Jalkanen et al., 2012). Many ship engines still operate without any aftertreatment systems.

Most of the literature studies focus on $\mathrm{NO}_{\mathrm{x}}, \mathrm{SO}_{\mathrm{x}}$, and $\mathrm{PM}$ emissions. Recent publications have been concerned with nanoparticle emissions and their measurement (see a recent review paper by Kumar et al., 2013). The studies have been carried out in the following ways: by performing tests in laboratory conditions on engine test beds (Kasper et al., 2007; Lyyränen et al., 1999; Petzold et al., 2008, 2010); by performing tests on-board ship from the ship pipe (Agrawal et al., 2008; Fridell et al., 2008; Juwono et al., 2013; Moldanová et al., 2009, 2013; Murphy et al., 2009); by taking measurements from ship plumes by aircraft (Berg et al., 2012; Chen et al., 2005; Murphy et al., 2009; Petzold et al., 2008; Sinha et al., 2003) or by ship (Lack et al., 2009; Williams et al., 2009); and by performing stationary measurements in port areas (Alföldy et al., 2013; Ault et al., 2009; Healy et al., 2009; Isakson et al., 2001; Jonsson et al., 2011). The reported emission factors are in the range of 2.9-44 and 22$109 \mathrm{~g}(\mathrm{~kg} \text { fuel })^{-1}$ for $\mathrm{SO}_{2}$ and $\mathrm{NO}_{\mathrm{x}}$, respectively, in the range of $(0.2-6.2) \times 10^{16}(\mathrm{~kg} \text { fuel })^{-1}$ for particle number, and in the range of $0.5-5.3 \mathrm{~g}(\mathrm{~kg} \text { fuel })^{-1}$ for $\mathrm{PM}_{2.5}$. Typically, a bimodal number size distribution was found; the nucleation mode peaked at $<20 \mathrm{~nm}$ and the Aitken mode at $50-100 \mathrm{~nm}$. Ship emissions are one of the least-regulated sources of anthropogenic emissions (Eyring et al., 2005). The International Maritime Organization (IMO), which is responsible for the international regulations of pollutants from ships, has set the emission limits for $\mathrm{NO}_{\mathrm{x}}$ and $\mathrm{SO}_{\mathrm{x}}$ in the revised Marpol Annex VI rules (IMO, 1998). National or regional regulations call for even more stringent limits than those given by the IMO. For example, in June 2004, the EU environment ministers agreed on a $1.5 \%$ sulphur (by mass) limit for fuels used by all ships in the Baltic Sea, North Sea and English Channel (Eyring et al., 2005), and currently the use of $0.1 \%$ sulphur by seagoing ships at berth is required in EU ports (European Union, 2012). Additionally, because the Baltic Sea is an emission control area for $\mathrm{SO}_{\mathrm{x}}$ (SECA), the ships operating there must use reduced-sulphur fuels (fuel sulphur content less than or equal to $1 \%$ by mass) since 1 July 2010 , and this will be decreased to $0.1 \%$ in January 2015 . The Baltic Sea is a busy area for short-sea marine traffic; about 3500-5000 different vessels are in operation every month (Jalkanen et al., 2012).

This study is a part of the SNOOP (Shipping-Induced $\mathrm{NO}_{\mathrm{x}}$ and $\mathrm{SO}_{\mathrm{x}}$ Emissions - Operational Monitoring Network) project which aims to find out how ship exhaust emissions are effecting to marine environment and human health in harbour areas. The more specific objectives of this work are to measure and characterise the emissions of regularly operating ships equipped with different after-treatment systems under winter and summer conditions in two different environments in Finland.

\section{Experimental methods}

\subsection{Measurement sites}

The measurements of ship emissions by a mobile laboratory van called "Sniffer" (see Sect. 2.2) were performed in two different harbour environments in Finland: at the harbours in the Helsinki downtown area, and along the shipping channel in the city of Turku (Fig. 1). The wintertime campaigns were conducted in Helsinki on 18-29 January 2010 and 7 January25 February 2011, and in Turku on 2-28 February 2010 and 7-17 February 2011. The summertime campaigns were performed on 26 July-6 August 2010 and 25 July-15 September 2011 in Helsinki, and on 9-19 August 2010 and 1-10 August 2011 in Turku. Monitoring occurred in the morning at 07:00-12:00 LT and in the evening at 16:00-22:00 LT. During the winter campaigns the mean temperature was $-4.6 \pm$ $5.8^{\circ} \mathrm{C}$ in Helsinki and $-4.7 \pm 4.3^{\circ} \mathrm{C}$ in Turku. As is typical for Finnish winters, the variation was very high. The mean relative humidity was $83 \pm 6 \%$ for both locations. During the summer campaigns the temperature variation was lower, and the mean temperatures were $20 \pm 3{ }^{\circ} \mathrm{C}$ and $19 \pm 1{ }^{\circ} \mathrm{C}$ for Helsinki and Turku, respectively, whereas the mean relative humidity varied highly between $40-90 \%$, the mean values being $73 \pm 8 \%$ in Helsinki and $66 \pm 11 \%$ in Turku.

Passenger traffic is busy at South Harbour, Helsinki. The Viking Line ships daily operate between Helsinki and Stockholm, and Helsinki and Tallinn from the Katajanokka terminal (sites 1 and 2 in Fig. 1). The Tallink Silja Line ships daily operate from the Olympic terminal (site 4) between Helsinki and Stockholm and from the Makasiini terminal (site 3) to St. Petersburg and Tallinn. All of these ships are passenger ships 


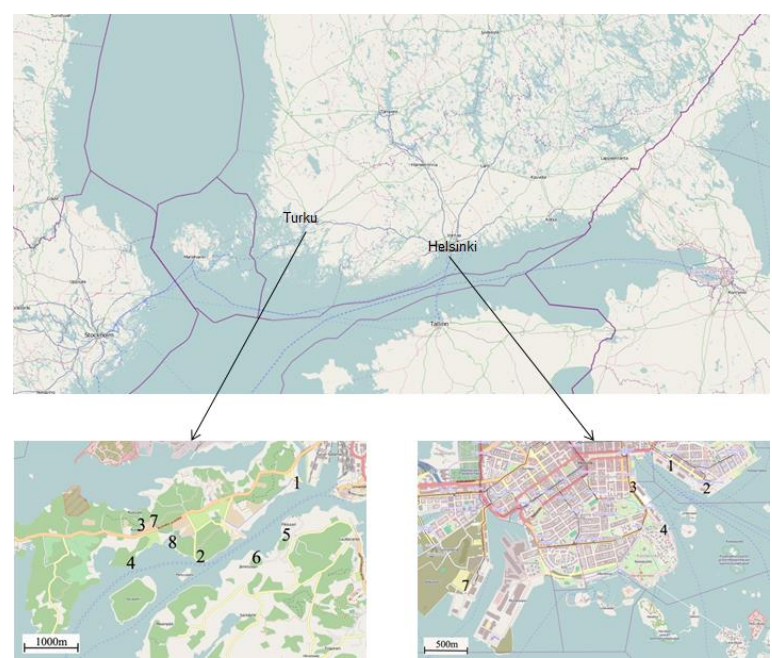

Fig. 1. Measurement sites in Helsinki South Harbour (sites 1-4) and West Harbour (site 7), and along the shipping channel near Turku Harbour (sites 1-8). ( ${ }^{\circledR}$ OpenStreetMap contributors, CC BY-SA, see http://www.openstreetmap.org/).

but also they provide roll-on roll-off service (ROPAX ships), and in fact, many cars and trucks travel on them. Additionally, during summertime many cruisers visit South Harbour (sites 1-4) and West Harbour (site 7). Pollutants from other local sources such as city traffic and a power plant located at a distance of $2 \mathrm{~km}$ from South Harbour affect air quality in the harbours as well. For example, the $\mathrm{SO}_{2}$ concentrations measured in the harbour area are highest with south-easterly wind due to the ships and with northerly wind due to the power plant (Fig. 2).

The measurement site was chosen according to the wind direction, so that with southerly wind Sniffer was stationed at sites 1 and 2, with easterly or north-easterly wind at sites $3-4$, and with southerly wind in summer at site 7 .

Furthermore, ships of Tallink Silja Line and Viking Line operate daily between Turku and Stockhom, departing from Turku Harbour. The passenger and freight traffic regularly occurs in the mornings and evenings. Depending on the wind direction, each measurement site (1-8 in the left side panel, Fig. 1) along the shipping channel was chosen so that the ship plume would likely enter the sampling inlet of Sniffer. The distance of the measurement site from the ship line varied between 100 and $1000 \mathrm{~m}$, and the measurement sites were located within a distance of around $5 \mathrm{~km}$ from the harbour. Other local sources were minimal, since no busy roads and only a few buildings were close to the sites. However, northern winds might transport pollution from the city centre and harbour to the measurement sites (Fig. 3).

With south-westerly or north-easterly wind, Sniffer was stationed at sites 1 and 5, with easterly or westerly wind at site 2 , and with southerly or south-westerly wind at sites 3 , 4,7 and 8 , even though site 4 was used with north-easterly wind as well. (a)

(b)
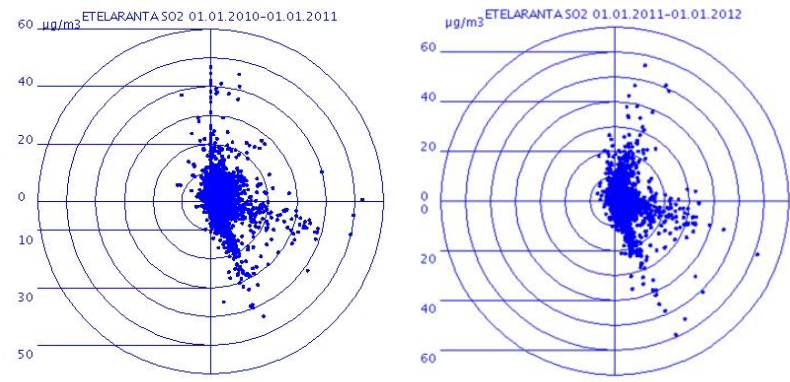

Fig. 2. Hourly $\mathrm{SO}_{2}$ concentrations in $\mu \mathrm{g} \mathrm{m}^{-3}$ at South Harbour, Helsinki, during the years 2010 (a) (Malkki et al., 2011), and 2011 (b) (Malkki et al., 2012). Wind directions from north $=0^{\circ} / 360^{\circ}$, east $=90^{\circ}$, south $=180^{\circ}$, west $=270^{\circ}$.

\subsection{Instrumentation for mobile measurements}

Monitoring was conducted with a mobile laboratory van, "Sniffer" (VW LT35 diesel van) described in detail in Pirjola et al. (2004, 2006, 2012). Sniffer was parked at the measurement site, facing the ship plume. The sampling occurred at $2.4 \mathrm{~m}$ height from the ground level, above the van's windshield. All instruments were zero-checked and synchronised before the start of the measurements.

Particle number concentration and size distribution were measured with an ELPI (Electrical Low Pressure Impactor, Dekati Ltd.) (Keskinen et al., 1992) equipped with a filter stage (Marjamäki et al., 2002) and an additional stage designed to enhance the particle size resolution for nanoparticles (Yli-Ojanperä et al., 2010). In the ELPI, the particles with aerodynamic diameters in the size range of $7 \mathrm{~nm}-10 \mu \mathrm{m}$ are first charged and then classified into 12 stages with a time resolution of $1 \mathrm{~s}$. The cut-off diameters of the ELPI stages are 0.016 (additional stage), 0.030, 0.056, 0.093, 0.156, 0.264, $0.385,0.617,0.954,1.610,2.410$, and $9.97 \mu \mathrm{m}$. The uncertainty of the measurement results of the ELPI is difficult to estimate since no clear information of the performance characteristics of the instrument was available from the manufacturer. However, based on the study by EURAMET (European Association of National Metrology Institutes) it is some tens of percent (Schlatter, 2010). In some of our measurements, a thermodenuder TD (Rönkkö et al., 2011) was used to study particle volatility characteristics at the maximum operating temperature of $265^{\circ} \mathrm{C}$. For these cases, the ELPI measured the plume after the TD, and another ELPI (without the additional stage) was installed before the TD. The particle concentrations were corrected for particle losses in the TD.

A DustTrak (TSI, model 8530) with a $2.5 \mu \mathrm{m}$ cut-off size was used to measure the real-time $\mathrm{PM}_{2.5}$ concentration (i.e. particles less than $2.5 \mu \mathrm{m}$ in aerodynamic diameter) with a time resolution of $1 \mathrm{~s}$. The DustTrak operates based on a 


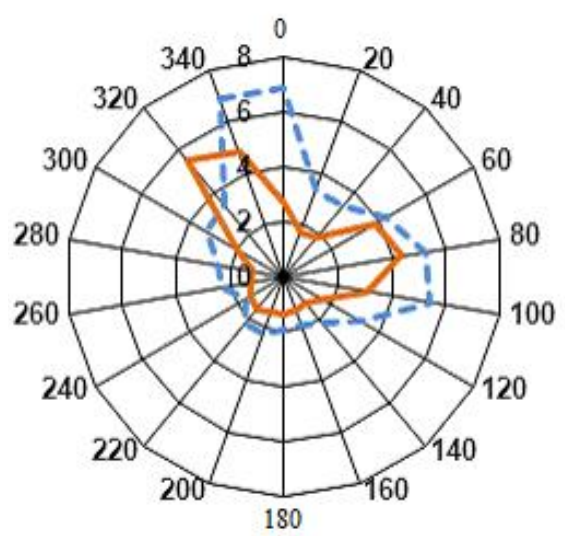

Fig. 3. Hourly $\mathrm{SO}_{2}$ concentration in $\mu \mathrm{g} \mathrm{m}^{-3}$ in Ruissalo, Turku, during the years 2010 and 2011 (Turku, 2011). Also shown is wind direction $\left({ }^{\circ}\right)$ outside the outermost circle.

light scattering technique, in which the amount of the scattered light is proportional to the volume concentration of the aerosol. The instrument was factory-calibrated with Arizona dust particles. Different correction factors for DustTraks under various environments have been published (e.g. Morawska et al., 2003; Wierzbicka, 2008). However, in this work the relative $\mathrm{PM}_{2.5}$ values are sufficient for the calculation of the emission factors, and thus absolute $\mathrm{PM}_{2.5}$ values are not needed.

Gaseous concentrations of $\mathrm{CO}_{2}$ (model VA 3100, Horiba), $\mathrm{CO}$ (model CO12M, Environnement S.A.), nitrogen oxides $\mathrm{NO}, \mathrm{NO}_{2}$ and $\mathrm{NO}_{\mathrm{x}}$ (model APNA 360, Horiba), and $\mathrm{SO}_{2}$ (Thermo Environmental Instruments, model $43 \mathrm{C}$ ) were monitored above the windshield of Sniffer at the same altitude as particle concentrations, with a time resolution of $1 \mathrm{~s}$. The expanded uncertainty of the gas analysers including the contribution of major components of the performance characteristics of the analysers and the traceable calibration lays approximately $\pm 10 \%$ but increases considerably at low concentration levels (ambient background concentration). The uncertainty calculations and the calibration service of the analysers were provided by the calibration laboratory of the Finnish Meteorological Institute, which is designated as a standard laboratory for the air quality in Finland by the Centre for Metrology and Accreditation.

A weather station on the roof of the van at a height of $2.9 \mathrm{~m}$ above ground level provided meteorological parameters. Relative wind speed and direction were measured with an ultrasonic wind sensor (model WAS425AH, Vaisala); the temperature and relative humidity with temperature and humidity probes (model HMP45A, Vaisala). Additionally, a global positioning system (model GPS V, Garmin) recorded the van's speed and the driving route. The distance between Sniffer and the ship in question was continuously measured by a Newcon Optik laser rangefinder monocular (LRM2500) up to $2.285 \mathrm{~km}$.
All instruments were synchronised with the GPS time, and zero-checked before and after the measurements.

\subsection{Ship characterisation}

In this work, the emissions of 11 ships were studied when they were operating normally. The main engines of all the ships were marine diesel engines which used HFO as fuel. Four of the ships were equipped with the SCR (selective catalytic reduction) system, one used the HAM (humid air motor) method, and two the DWI (direct water injection) method to decrease $\mathrm{NO}_{\mathrm{x}}$ emissions (Table 1). Also given in Table 1 is the maximum power of the four main engines.

\subsection{Emission parameters}

The emission ratio, $\mathrm{ER}_{X}$, is defined as a ratio of the excess concentration of $X$ emitted from a source divided by the excess concentration of $\mathrm{CO}_{2}$ emitted by the source:

$\mathrm{ER}_{X}=\frac{X-X_{\mathrm{bg}}}{\mathrm{CO}_{2}-\mathrm{CO}_{2, \mathrm{bg}}}=\frac{\Delta X}{\Delta \mathrm{CO}_{2}}$,

where $X$ is gaseous or particle number or mass concentration, and $X_{\text {bg }}$ and $\mathrm{CO}_{2 \text {,bg }}$ are background concentrations. ER $\mathrm{E}_{X}$ can as well be calculated directly from the regression slope of the concentration of $\Delta X$ to that of $\Delta \mathrm{CO}_{2}$ (Andreae and Merlet, 2001). If the instruments measuring $X$ and $\mathrm{CO}_{2}$ have about the same time response, the peak concentrations of $X$ and $\mathrm{CO}_{2}$ can be used to calculate the ER and EF (emission factor), otherwise the integrals have to be used (Schlager et al., 2007; Petzold et al., 2008). For comparison, we calculated the emission ratios and emission factors in this work in both ways.

Since in this work, the gases $\left(\mathrm{SO}_{2}, \mathrm{NO}, \mathrm{NO}_{2}, \mathrm{NO}_{\mathrm{x}}\right.$, $\mathrm{CO}_{2}$ ) were measured in ppm, number concentration in particles $\mathrm{cm}^{-3}$, and PM concentration in $\mu \mathrm{g} \mathrm{m}^{-3}$, the units of $\mathrm{ER}_{X}$ are ppm ppm ${ }^{-1}$ for gases, $\# \mathrm{~cm}^{-3} \mathrm{ppm}^{-1}$ for $N_{\text {tot }}$, and $\mu \mathrm{g} \mathrm{m}^{-3} / \mu \mathrm{g} \mathrm{m}^{-3}$ for $\mathrm{PM}_{2.5}$ if the $\mathrm{CO}_{2}$ concentration is converted to a mass unit by the ideal gas law at normal temperature and pressure (NTP) conditions $(T=293.15 \mathrm{~K})$.

The emission factor, $\mathrm{EF}_{X}\left(\mathrm{~g} \mathrm{~kg}^{-1}\right)$, is the amount of compound $X$ released per amount of fuel burned and can be expressed as

$\mathrm{EF}_{X}=\mathrm{ER}_{X} \cdot \frac{M_{X}}{M_{\mathrm{CO}_{2}}} \cdot \mathrm{EF}_{\mathrm{CO}_{2}}$

for gases,

$\mathrm{EF}_{N_{\text {tot }}}=\mathrm{ER}_{N_{\text {tot }}} \frac{R T}{p \cdot M_{\mathrm{CO}_{2}}} \cdot \mathrm{EF}_{\mathrm{CO}_{2}}$

for particle number concentration,

$\mathrm{EF}_{\mathrm{PM}_{2.5}}=\mathrm{ER}_{\mathrm{PM}_{2.5}} \cdot \mathrm{EF}_{\mathrm{CO}_{2}}$

for particle mass concentration, 
where $M_{X}$ and $M_{\mathrm{CO}_{2}}$ are the mole masses of the gases $X$ and $\mathrm{CO}_{2}$, and $\mathrm{EF}_{\mathrm{CO}_{2}}$ is the emission factor of the reference species $\mathrm{CO}_{2}$. In this work we used a value of $3107 \mathrm{~g}(\mathrm{~kg} \text { fuel })^{-1}$ burned (Petzold et al., 2008). Note that for particle number concentration, the unit of EF is particles $(\mathrm{kg} \text { fuel })^{-1}$ burned.

\subsection{Fuel sulphur content}

If the emission factor of $\mathrm{CO}_{2}$ and fuel sulphur content FSC (ppmM) are known, the ratio of $\mathrm{S}$ atoms and $\mathrm{CO}_{2}$ molecules in one gram fuel burnt is

$\frac{\mathrm{FSC} \cdot N_{\mathrm{A}}}{M_{\mathrm{S}}} / \frac{\mathrm{EF}_{\mathrm{CO}_{2}} \cdot N_{\mathrm{A}}}{M_{\mathrm{CO}_{2}}}=\frac{\mathrm{FSC}}{\mathrm{EF}_{\mathrm{CO}_{2}}} \cdot \frac{M_{\mathrm{CO}_{2}}}{M_{\mathrm{S}}}$,

where $N_{\mathrm{A}}$ is the Avogadro's constant and $M_{\mathrm{CO}_{2}}$ and $M_{\mathrm{S}}$ are the mole masses of $\mathrm{CO}_{2}$ and $\mathrm{S}$. If all sulphur in the fuel is assumed to have been oxidised to $\mathrm{SO}_{2}$, Eq. (3) is approximately equal to the ratio of the measured $\mathrm{SO}_{2}$ and $\mathrm{CO}_{2}$ concentrations integrated under the peaks over the background concentrations. Therefore, FSC in \% can be calculated by the following equation:

$$
\begin{aligned}
\mathrm{FSC}(\%) & =\frac{\Delta \mathrm{SO}_{2}(\mathrm{ppb}) \times 10^{-3}}{\Delta \mathrm{CO}_{2}(\mathrm{ppm})} \cdot \frac{M_{\mathrm{S}}}{M_{\mathrm{CO}_{2}}} \cdot \mathrm{EF}_{\mathrm{CO}_{2}} \cdot 100 \\
& \approx \frac{\Delta \mathrm{SO}_{2}(\mathrm{ppb})}{\Delta \mathrm{CO}_{2}(\mathrm{ppm})} \cdot 0.23 .
\end{aligned}
$$

It should be noted that a minor part of the fuel sulphur - less than $6 \%$ as reported by Alföldy et al. (2013) and even $0.7 \%$ as measured by Moldanová et al. (2013) - might be emitted as $\mathrm{SO}_{3}$ or converted to $\mathrm{H}_{2} \mathrm{SO}_{4}$ by homogeneous and heterogeneous pathways in the atmosphere. Thus Eq. (4) yields lower limits for FSC (Williams et al., 2009).

\section{Results and discussion}

\subsection{General overview of the harbour measurements}

As an example, Fig. 4 illustrates a typical time series of particle number concentration and gaseous species in the Katajanokka harbour (site 2, Fig. 1) in the morning on 8 September 2011, and near the Turku harbour (site 4, Fig. 1) in the evening on 9 August 2010.

Some interesting features can be observed. First, approaching or departing ships are easily distinguished from the background. Of course, Sniffer's ability to catch the plume is very sensitive to the meteorological conditions, especially to the wind speed, direction and buoyance forces. In the Helsinki case, three ships (E, D and A; Table 1) arrived at the harbour at 09:40, 09:47, and 10:22, respectively; the last one left the harbour at 11:37. The peak concentrations of particles and gases were observed simultaneously. In Turku, three ships (G, I, and K; Table 1) arrived at the harbour first, passing Sniffer at 18:58, 19:30 and 19:34, respectively. Later in the evening they left the harbour in the same order and again passed Sniffer at 21:06, 21:11 and 21:15. Sniffer was first parked at site 4 (Fig. 1), but because only weak gaseous peaks were monitored, Sniffer was turned on at 20:00 and driven to site 2 (Fig. 1). Sniffer's own exhaust caused the small peaks in particle concentration at around 20:00. At the new site the background $\mathrm{CO}_{2}$ concentration was somewhat higher than at the first site. Typically, the peak particle concentrations varied in the range of $10^{4}-10^{6} \mathrm{~cm}^{-3}$ when the ships passed Sniffer at 200-800 $\mathrm{m}$ distance; the maximum values were $1.5 \times 10^{6}$ and $1.6 \times 10^{5} \mathrm{~cm}^{-3}$ in Helsinki and Turku, respectively. The highest $\mathrm{SO}_{2}$ concentrations measured during the campaigns were $168 \mathrm{ppb}$ in Helsinki and $38 \mathrm{ppb}$ in Turku.

Secondly, unloading and loading the passenger cars and trucks from/unto the ship occurred in Helsinki harbour at 10:33-11:18. This led to an increase in particles as well as $\mathrm{NO}_{\mathrm{x}}$ and $\mathrm{CO}_{2}$ concentrations, whereas no peak appeared in the $\mathrm{SO}_{2}$ concentration. The smallest nucleation mode particles $(<30 \mathrm{~nm})$ dominate vehicles' exhaust emissions, whereas for ships the particles larger than $30 \mathrm{~nm}$ are more abundant.

Third, the local background concentration in Helsinki was higher than in Turku. A more detailed comparison of the background particle characters can be seen in Table 2 and Fig. 5. The average background concentrations were calculated by taking into account the lowest 5 percent of the measured values of each measurement periods. The average values were then classified according to the location (Helsinki or Turku), season (winter or summer), and time of day (morning or evening). At each site the concentrations were consistently higher in winter compared to summer. When the wind blew from the sea (south), the average number concentration was around $10^{4} \mathrm{~cm}^{-3}$ or even somewhat lower, and variation was rather small. However, sites 1, 4 and 5 in Turku and sites 3 and 4 in Helsinki occasionally suffer from north-easterly wind, which carries pollutants from the city centre, and, in Turku also from the harbour. In these cases, the standard deviations are much higher as well.

In winter the nucleation mode is much stronger than in summer, whereas the differences observed in the accumulation mode were not so significant (Fig. 5). The reason might be the lower ambient temperature, which brings down the saturation ratio of the condensing vapours and thus favours nucleation as well (e.g. Pirjola et al., 2006). Additionally, the height of the mixing layer varies between winter and summer, influencing the dilution of the pollutants. The concentrations are higher in the morning due to the busy morning traffic, energy production and smaller vertical mixing than in the afternoon. This kind of behaviour has been found in many vehicle studies as well (e.g. Molnár et al., 2002; Wehner et al., 2002; Virtanen et al., 2006; Pirjola et al., 2012). 
Table 1. Technology parameters of the ships. $\mathrm{SRC}=$ selective catalytic reduction, HAM = humid air motor, DWI $=$ direct water injection, $\mathrm{CC}=$ catalytic converter.

\begin{tabular}{|c|c|c|c|c|c|c|c|}
\hline Ship & Ship type & $\begin{array}{l}\text { Engine } \\
\text { manufacturer }\end{array}$ & Engine model & $\begin{array}{l}\text { Main } \\
\text { engines }\end{array}$ & $\begin{array}{l}\text { After- } \\
\text { treatment } \\
\text { system }\end{array}$ & $\begin{array}{l}\text { Max. } \\
\text { power } \\
\text { (MW) }\end{array}$ & Year \\
\hline A & ROPAX & Wärtsilä & $46 \mathrm{~F}$ & 4 & SCR & 40.0 & 2008 \\
\hline B & ROPAX & Wärtsilä & $16 \mathrm{~V} 32$ & 4 & SCR & 32.0 & 2008 \\
\hline $\mathrm{C}$ & ROPAX & Wärtsilä & $12 \mathrm{~V} 46 \mathrm{C}$ & 4 & NONE & 50.4 & 2008 \\
\hline $\mathrm{D}$ & ROPAX & Wärtsilä & $12 \mathrm{PC} 2-6 \mathrm{~V}-400$ & 4 & HAM & 23.0 & 1985 \\
\hline $\mathrm{E}$ & ROPAX & Wärtsilä & $9 \mathrm{R} 46$ & 4 & DWI & 32.6 & 1991 \\
\hline $\mathrm{F}$ & ROPAX & Wärtsilä & $9 \mathrm{R} 46$ & 4 & DWI & 32.6 & 1990 \\
\hline G & ROPAX & MAN & 6L58/64 & 4 & SCR & 31.8 & 1993 \\
\hline $\mathrm{H}$ & ROPAX & Wärtsilä & $16 \mathrm{~V} 32$ & 4 & SCR & 26.2 & 2006 \\
\hline I & ROPAX & Pielstick & $12 \mathrm{PC} 2-6 \mathrm{~V}-400$ & 4 & NONE & 23.8 & 1989 \\
\hline $\mathrm{J}$ & ROPAX & Pielstick & $12 \mathrm{PC} 2-6 \mathrm{~V}-400$ & 4 & NONE & 23.8 & 1988 \\
\hline K & ROPAX & $\mathrm{MaK}$ & $8 \mathrm{M} 453 \mathrm{AK}$ & 4 & NONE & 7.4 & 1972 \\
\hline
\end{tabular}
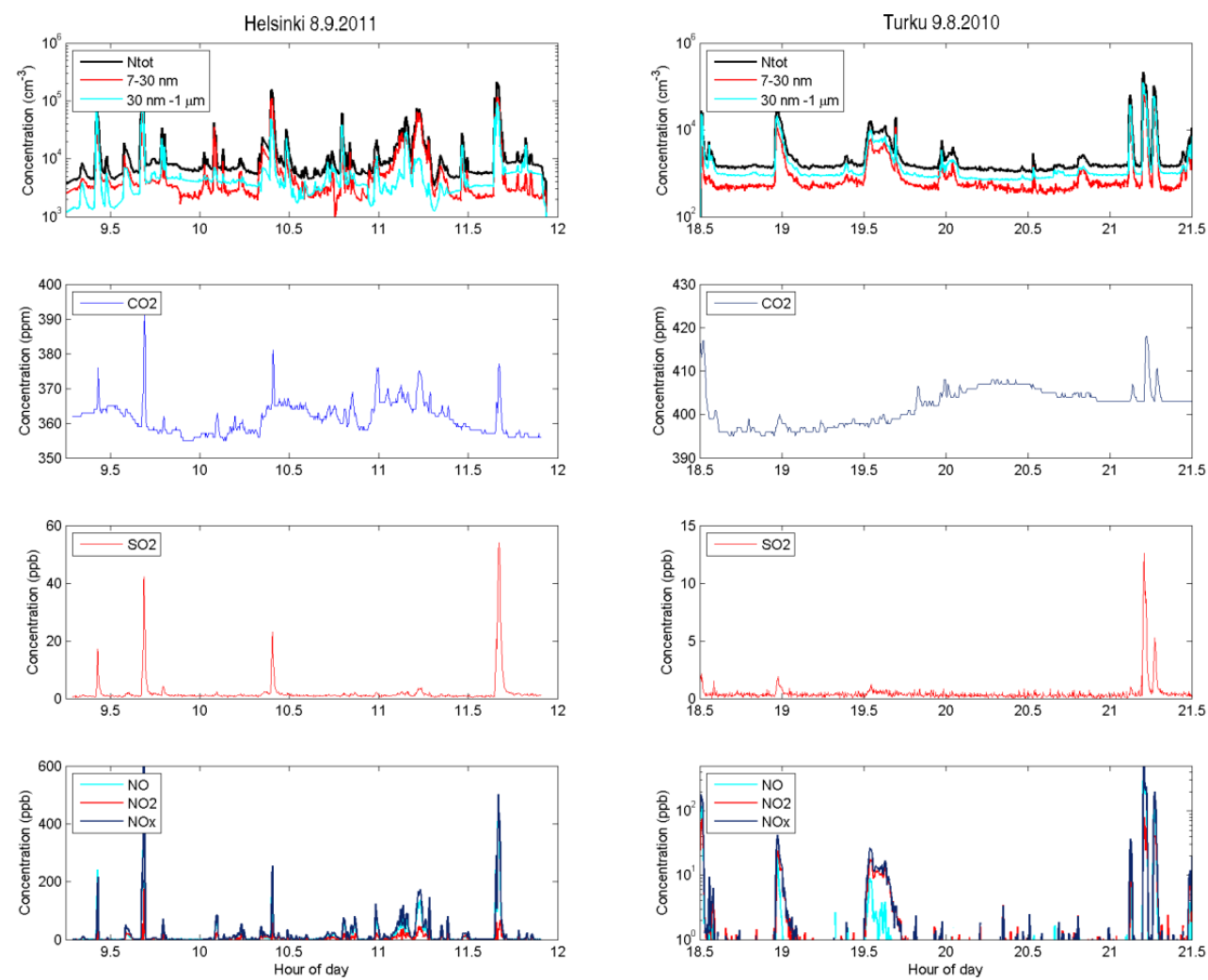

Fig. 4. Shown are time series of particle number concentration, gaseous $\mathrm{CO}_{2}, \mathrm{SO}_{2}, \mathrm{NO}, \mathrm{NO}_{2}$ and $\mathrm{NO}_{\mathrm{x}}$ in Helsinki on 8 September 2011 (left side) and in Turku on 9 August 2010 (right side). Besides total number concentration, concentrations of particles smaller than $30 \mathrm{~nm}$ and in the range of $30-1000 \mathrm{~nm}$ are shown as well.

\subsection{Size distributions of the ship particles}

Figure 6 illustrates the time series of particle number size distributions for the same measurement periods as in Fig. 4. The ship peaks take around $3 \mathrm{~min}$, and can easily be distinguished from the background. Particle number and volume size distributions were plotted for four selected ships (D, E, G and I, Table 1) using different after-treatment systems (Fig. 7). For each of these ships, 7-16 successful size distributions were measured. The GPS data from the ships and our own distance measurements by the laser rangefinder showed that along the narrow shipping channel near Turku, all ships 
(a)
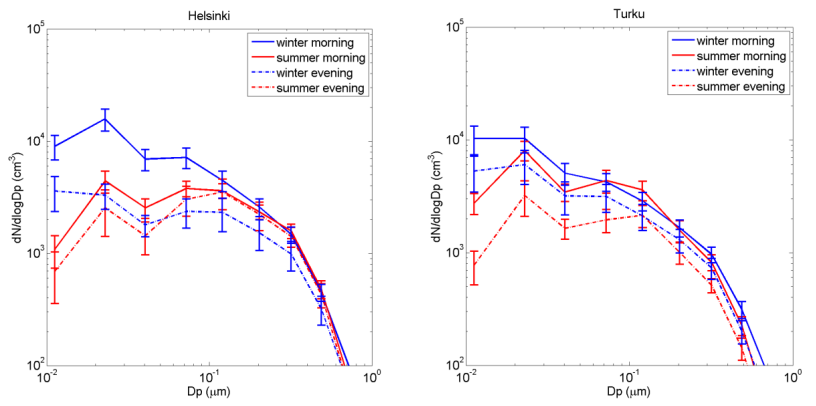

Fig. 5. Average number size distributions of background particles during winter and summer in Helsinki (a) and in Turku (b). Also shown are the curves for morning and evening measurements. Error bars refer to the standard deviations.

operated with a constant speed of around 8.4 knots and most likely with a constant engine load. The plots show the averaged normalised size distributions, i.e. for each ship the background size distribution was subtracted from the measured size distribution, and then the result was divided by the excess $\mathrm{CO}_{2}$ concentration to remove the effect of dilution; after that the average size distribution for an individual ship along with standard deviation was calculated. This was done for the peak maximum size distribution as well as for the $50 \%$ and $75 \%$ of the integrated peak. Because no large variation was observed, we present here only the size distributions for the peak maximum values. Two modes were fitted, and the modal parameters (number or volume concentration of the mode divided by the excess $\mathrm{CO}_{2}$ concentration in the units $\mathrm{cm}^{-3} \mathrm{ppm}^{-1}$ or $\mu \mathrm{m}^{3} \mathrm{~cm}^{-3} \mathrm{ppm}^{-1}$, geometric mean diameter $D_{\mathrm{g}}$ in $\mu \mathrm{m}$, and standard deviation $\sigma_{\mathrm{g}}$ ) for the Aitken (or the nucleation mode if present) and the accumulation (or soot) modes are given in Table 3.

Regarding the number size distributions, for all ships the Aitken modes were dominant and peaked at around 20$30 \mathrm{~nm}$. The accumulation modes typically peaked at 80 $100 \mathrm{~nm}$. In winter, the ships requiring water for the aftertreatment systems (HAM and DWI) had clearly higher particle number and volume emissions than the others. At the same time the emitted particles were larger. The smallest particulate emissions were observed to come from the ship equipped with the SCR system. In summer, the differences between the ships were not significant, with the exception of the DWI ship.

When considering the volume size distributions, the accumulation mode was dominant and the Aitken mode particles can hardly be distinguished. The accumulation modes peaked at $400-500 \mathrm{~nm}$ for the HAM and DWI ships, and at around $200 \mathrm{~nm}$ for the others. Similar results have been reported in the literature. For example, Moldanová et al. (2009) studied a ship diesel engine on board, and found that in the hot exhaust, the mass size distribution showed two main modes: one being (a)

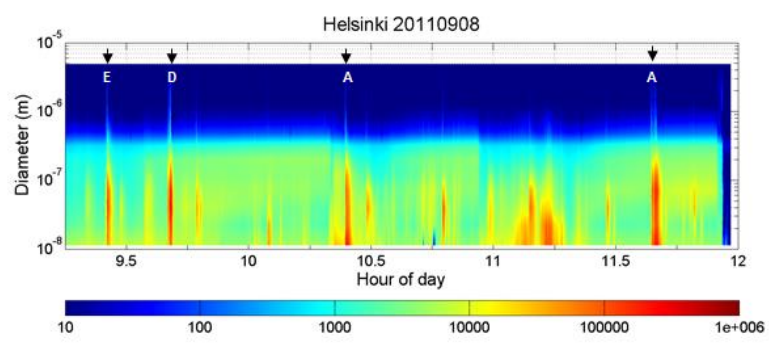

(b)

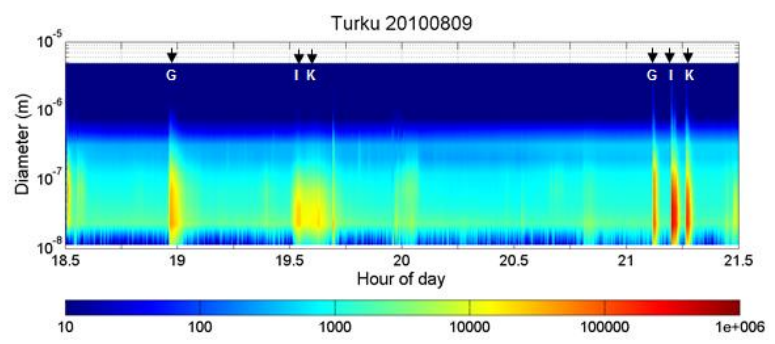

Fig. 6. Time series of particle number size distributions $\mathrm{d} N / \operatorname{dlog} D_{\mathrm{p}}\left(\mathrm{cm}^{-3}\right)$ in Helsinki (a) and Turku (b) for the same time periods as in Fig. 4. The $y$ axis refers to particle diameter $D_{\mathrm{p}}$ in $\mathrm{m}$. Colour bar shows the concentration $\mathrm{d} N / \mathrm{d} \log D_{\mathrm{p}}\left(\mathrm{cm}^{-3}\right)$. The ships are marked by arrows and denominated according to Table 1.

the accumulation mode at the diameter around $0.5 \mu \mathrm{m}$ and the other being the coarse mode at $7 \mu \mathrm{m}$. Additionally, Fridell et al. (2008) found a third peak in the diameter range 100$200 \mathrm{~nm}$ in the hot exhaust. Isakson et al. (2001) reported that when the ship plume was emitted about $600 \mathrm{~m}$ from the instruments, the dominant mode of the number size distribution was in the diameter range below $40 \mathrm{~nm}$, and a weaker mode in the range of $70-100 \mathrm{~nm}$. The airborne measurements by Petzold et al. (2008) showed that although the ship plume ages two modes were peaking at $14 \mathrm{~nm}$ and at $90-100 \mathrm{~nm}$, measured in dry conditions.

In regard to all ships, the average total number concentration increases as $\mathrm{SO}_{2}$ concentration increases (Fig. 8) indicating that at least a part of the nucleation mode particles might be formed by $\mathrm{H}_{2} \mathrm{SO}_{4}-\mathrm{H}_{2} \mathrm{O}$ nucleation. This is in agreement with Petzold et al. (2008) who concluded that the smallest particles $(<30 \mathrm{~nm})$ were composed predominantly of sulphuric acid water clusters while the large combustion particle mode contains most of the non-volatile black carbon, organic carbon and ash. In addition, Lack et al. (2009) suggested that the reason for the nucleation mode particles is very fast formation of small sulphuric acid particles that subsequently grow by condensation and coagulation. Furthermore, they found that emissions of sulphate and organic matter linearly correlate with fuel sulphur content, while emissions of black carbon are heavily dependent on engine type. 
(a)

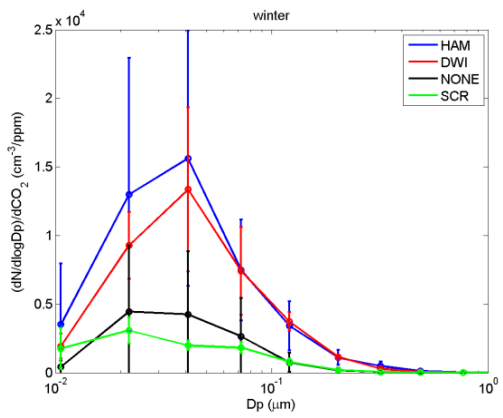

(b)

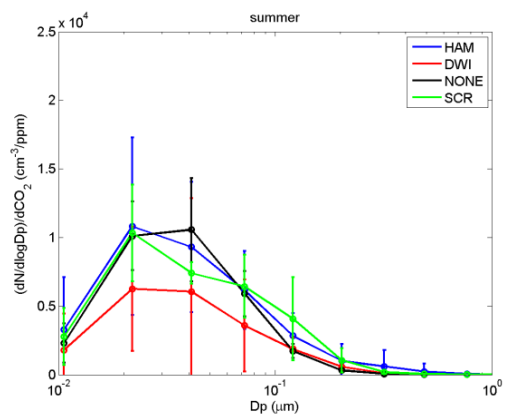

(c)

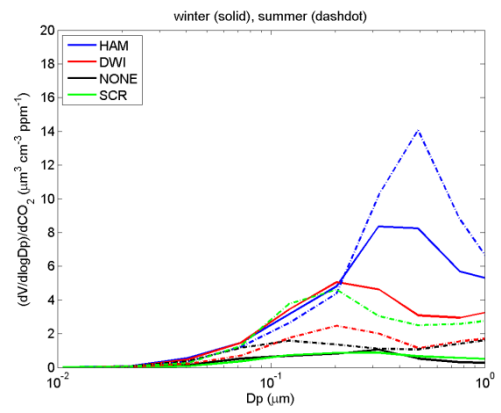

Fig. 7. Normalised number size distributions for winter (a) and summer (b) for the ships using different after-treatment systems. The corresponding volume size distributions are presented in (c). The error bars show the standard deviations.

Table 2. Average background number concentrations with standard deviations during the harbour measurements.

\begin{tabular}{|c|c|c|c|c|c|c|c|}
\hline \multicolumn{4}{|c|}{ Helsinki } & \multicolumn{4}{|c|}{ Turku } \\
\hline Site & $\begin{array}{l}\text { Wind } \\
\text { direction }\end{array}$ & $\begin{array}{l}N_{\text {tot }} \\
\left(10^{3} \mathrm{~cm}^{-3}\right) \\
\text { winter }\end{array}$ & $\begin{array}{l}N_{\text {tot }} \\
\left(10^{3} \mathrm{~cm}^{-3}\right) \\
\text { summer }\end{array}$ & Site & $\begin{array}{l}\text { Wind } \\
\text { direction }\end{array}$ & $\begin{array}{l}N_{\text {tot }} \\
\left(10^{3} \mathrm{~cm}^{-3}\right) \\
\text { winter }\end{array}$ & $\begin{array}{l}N_{\text {tot }} \\
10^{3} \mathrm{~cm}^{-3} \text { ) } \\
\text { summer }\end{array}$ \\
\hline 1,2 & $\mathrm{~S}$ & $8.8 \pm 1.4$ & $7.8 \pm 2.3$ & 1,5 & SW, NE & $22.3 \pm 4.3$ & $11.9 \pm 1.4$ \\
\hline 3 & $\mathrm{E}, \mathrm{NE}$ & $32.6 \pm 5.3$ & $12.4 \pm 9.4$ & 2 & $\mathrm{~W}, \mathrm{E}$ & $11.3 \pm 2.1$ & $8.8 \pm 1.3$ \\
\hline 4 & $\mathrm{E}, \mathrm{NE}$ & $51.1 \pm 4.9$ & $7.1 \pm 4.3$ & 3,7 & S, SW & $9.8 \pm 1.6$ & $6.8 \pm 1.3$ \\
\hline 7 & S & - & $7.2 \pm 2.4$ & 4 & S, SW, NE & $21.0 \pm 3.7$ & $16.2 \pm 3.2$ \\
\hline & & & & 8 & $\mathrm{~S}, \mathrm{SW}$ & - & $6.3 \pm 1.0$ \\
\hline
\end{tabular}

\subsection{Volatility properties of the ship particles}

Volatility properties of particles emitted from the ships on the way to the Turku harbour in 2011 were investigated with the use of a thermodenuder (TD) installed into the Sniffer prior to the ELPI (with the additional stage). Before the TD, the other ELPI simultaneously measured the plume at ambient temperature. The TD was heated to $265^{\circ} \mathrm{C}$, at which most of the volatile species are expected to have evaporated. The particle losses in the thermodenuder were corrected and the background concentrations were subtracted. There were five ships operating in the harbour, but due to the meteorological conditions during the campaign, we were able to observe 12 successful peaks for only two of the ships, ships $\mathrm{K}$ and I in Table 1.

As an example, Fig. 9 illustrates the averaged number and volume size distributions for ship $\mathrm{K}$, based on the peak values of the particles. Also shown in Fig. 9 are the size distributions for the non-volatile particles measured after the TD treatment. The error bars describe standard deviations. The size distributions for all other analysed ships showed rather similar behaviour. As seen in Fig. 9a, the number size distribution of the non-volatile particles was bimodal: the nucleation mode $\left(N_{\text {tot }} \sim 2.3 \times 10^{4} \mathrm{~cm}^{-3}\right)$ peaked at $12 \mathrm{~nm}$ or less, and the accumulation $\left(N_{\text {tot }} \sim 5.8 \times 10^{3} \mathrm{~cm}^{-3}\right)$ mode at
$49 \mathrm{~nm}$. Note that the existence of particles even smaller than $7 \mathrm{~nm}$ (ELPI's detection limit) and thus with a modal diameter smaller than $12 \mathrm{~nm}$ cannot be ruled out. Jonsson et al. (2011) reported the nucleation mode diameter for the non-volatile particles to be in the range of $10.1-16.5 \mathrm{~nm}$. Without the TD treatment the particles were larger; the Aitken mode peaked at around $37 \mathrm{~nm}\left(N_{\text {tot }} \sim 2.5 \times 10^{4} \mathrm{~cm}^{-3}\right)$, and the accumulation $\left(N_{\text {tot }} \sim 1.5 \times 10^{3} \mathrm{~cm}^{-3}\right)$ mode at $93 \mathrm{~nm}$. Three lognormal modes, peaking at $86 \mathrm{~nm}, 256 \mathrm{~nm}$ and $1.8 \mu \mathrm{m}$, were fitted for the non-volatile volume size distribution, whereas for all particles two modes were fitted, peaking at $206 \mathrm{~nm}$ and $5.7 \mu \mathrm{m}$.

The non-volatile fraction of the particles was calculated to be in the range of $35-74 \%$ by number and $29-33 \%$ by volume. Petzold et al. (2008) used the DMPS (Differential Mobility Particle Sizer) measuring the particles $>13 \mathrm{~nm}$ and reported $34 \pm 3 \%$ by number and $29 \pm 3 \%$ by mass; on the other hand, Jonsson et al. (2011) reported values between 26 and $66 \%$ by number by using the EEPS (engine exhaust particle sizer) for the particle sizes $5.6-560 \mathrm{~nm}$.

\subsection{Emission factors}

For comparison, the emission parameters were calculated from the peak concentration values and from the integrated surface area. Since the results were very close to each other, we present here the results based on the peak values. As 
Table 3. Modal parameters (number concentration $\mathrm{N}$, geometric mean diameter $D_{\mathrm{g}}$, standard deviation $\sigma$ ) for the ships mentioned in Fig. 5 . Different after-treatment systems (ATS) are given in the first column.

\begin{tabular}{|c|c|c|c|c|c|c|c|c|c|c|c|c|}
\hline \multirow[b]{2}{*}{ ATS } & \multicolumn{2}{|c|}{$\begin{array}{l}\text { winter } \\
\text { Aitken mode } \\
N\end{array}$} & & \multicolumn{3}{|c|}{$\begin{array}{l}\text { winter } \\
\text { accumulation mode } \\
N\end{array}$} & \multicolumn{2}{|c|}{$\begin{array}{c}\text { summer } \\
\text { Aitken mode } \\
N\end{array}$} & \multicolumn{4}{|c|}{$\begin{array}{c}\text { summer } \\
\text { accumulation mode } \\
N\end{array}$} \\
\hline & $\begin{array}{c}\left(\mathrm{cm}^{-3}\right. \\
\left.\mathrm{ppm}^{-1}\right)\end{array}$ & $\begin{array}{r}D_{\mathrm{g}} \\
(\mathrm{nm})\end{array}$ & $\sigma$ & $\begin{array}{c}\left(\mathrm{cm}^{-3}\right. \\
\left.\mathrm{ppm}^{-1}\right)\end{array}$ & $\begin{array}{r}D_{\mathrm{g}} \\
(\mathrm{nm})\end{array}$ & $\sigma$ & $\begin{array}{c}\left(\mathrm{cm}^{-3}\right. \\
\left.\mathrm{ppm}^{-1}\right)\end{array}$ & $\begin{array}{r}D_{\mathrm{g}} \\
(\mathrm{nm})\end{array}$ & $\sigma$ & $\begin{array}{c}\left(\mathrm{cm}^{-3}\right. \\
\left.\mathrm{ppm}^{-1}\right)\end{array}$ & $\begin{array}{r}D_{\mathrm{g}} \\
(\mathrm{nm})\end{array}$ & $\sigma$ \\
\hline NONE & 2591 & 29 & 1.56 & 704 & 75 & 1.39 & 8358 & 33 & 1.92 & - & - & - \\
\hline HAM & 10535 & 31 & 1.85 & 1327 & 100 & 2.06 & 6869 & 26 & 1.77 & 2070 & 82 & 1.64 \\
\hline DWI & 7333 & 33 & 1.73 & 2246 & 85 & 1.85 & 3902 & 26 & 1.77 & 1524 & 75 & 1.81 \\
\hline SCR & 1934 & 19 & 1.77 & 776 & 77 & 1.60 & 5491 & 23 & 1.64 & 3100 & 82 & 1.64 \\
\hline
\end{tabular}

Table 4. Emission factors in NTP conditions $\left(p=1.013 \times 10^{5} \mathrm{~Pa}, T=293.15 \mathrm{~K}\right)$.

\begin{tabular}{llllll}
\hline ATS & $\mathrm{EF}_{\mathrm{NO}}\left(\mathrm{g}(\mathrm{kg} \mathrm{fuel})^{-1}\right)$ & $\mathrm{EF}_{\mathrm{NO}_{\mathrm{x}}}\left(\mathrm{g}(\mathrm{kg} \mathrm{fuel})^{-1}\right)$ & $\mathrm{EF}_{\mathrm{SO}_{2}}\left(\mathrm{~g}(\mathrm{~kg} \mathrm{fuel})^{-1}\right)$ & $\mathrm{EF}_{N_{\text {tot }}}\left(10^{16} \#(\mathrm{~kg} \text { fuel })^{-1}\right)$ & $\mathrm{EF}_{\mathrm{PM}}{ }_{2.5}(\mathrm{~g}(\mathrm{~kg} \mathrm{fuel})$ \\
\hline NONE & $42 \pm 6$ & $65 \pm 10$ & $9.8 \pm 1.0$ & $1.25 \pm 0.17$ & $2.54 \pm 0.40$ \\
NONE & $72 \pm 14$ & $86 \pm 13$ & $4.6 \pm 0.6$ & $1.86 \pm 0.27$ & $2.24 \pm 0.29$ \\
NONE & $53 \pm 9$ & $86 \pm 15$ & $8.7 \pm 1.9$ & $1.45 \pm 0.30$ & $1.58 \pm 0.82$ \\
NONE & $55 \pm 6$ & $76 \pm 6$ & $5.7 \pm 0.6$ & $0.39 \pm 0.19$ & $4.90 \pm 0.48$ \\
HAM & $34 \pm 8$ & $56 \pm 12$ & $3.5 \pm 0.1$ & $*$ & $2.87 \pm 2.05$ \\
DWI & $57 \pm 13$ & $100 \pm 23$ & $2.5 \pm 1.0$ & $1.34 \pm 0.62$ & $3.26 \pm 1.58$ \\
DWI & $47 \pm 29$ & $*$ & $2.26 \pm 0.83$ & $1.05 \pm 0.85$ \\
SCR & $49 \pm 6$ & $79 \pm 9$ & $9.9 \pm 0.1$ & $0.32 \pm 0.21$ & $1.00 \pm 1.58$ \\
SCR & $29 \pm 3$ & $44 \pm 4$ & $17.0 \pm 1.2$ & $1.38 \pm 0.20$ & $2.81 \pm 0.30$ \\
SCR & $18 \pm 1$ & $26 \pm 2$ & $5.4 \pm 0.7$ & $*$ & $2.19 \pm 0.33$ \\
SCR & $16 \pm 8$ & $25 \pm 15$ & $6.3 \pm 0.1$ & & \\
\hline
\end{tabular}

* A coefficient of determination $\left(R^{2}\right)$ for Emission Ratio-fit low, $<0.2$.

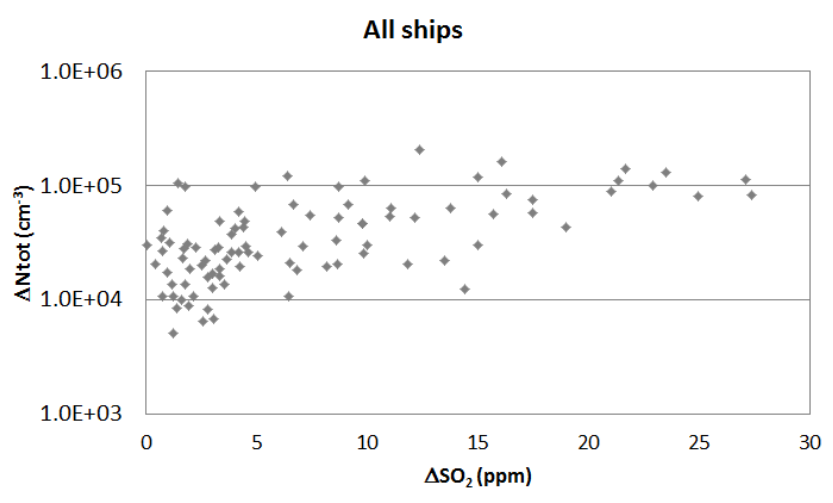

Fig. 8. Correlation of excess particle number concentration and excess $\mathrm{SO}_{2}$.

an example, Fig. 10 presents the emission ratios according to Eq. (1) for $\mathrm{NO}, \mathrm{NO}_{\mathrm{x}}, \mathrm{SO}_{2}, N_{\text {tot }}$, and $\mathrm{PM}_{2.5}$ for ship $\mathrm{G}$ (Table 1). Linear regression analysis was used to determine the slope of the line. The correlation coefficient is typically close to 0.90 , and even the smallest value found for the total number concentration is 0.84 . A possible explanation for this is that besides dilution, aerosol dynamics might have some effect on particle number concentration, whereas $\mathrm{CO}_{2}$ concentration depends only on dilution. On the other hand, many authors have reported for exhaust particles that dilution dominates and covers coagulation and condensation processes unless mixing is inefficient (see review paper by Kumar et al., 2011). Furthermore, during dilution $\mathrm{NO}_{\mathrm{x}}$ is inert but $\mathrm{NO}$ is able to oxidise with ozone to form $\mathrm{NO}_{2}$. This might cause some uncertainty in $\mathrm{EF}_{\mathrm{NO}}$. The time for the ship plume to transport from the source to the measurement site was at maximum 3-5 min. The conversion of $\mathrm{NO}_{2}$ to $\mathrm{HNO}_{3}$ and PAN is much slower (Chen et al., 2005; Williams et al., 2009).

The calculated emission factors for ship $G$ are $\quad \mathrm{EF}_{\mathrm{NO}} \sim 13 \pm 1 \mathrm{~g}(\mathrm{~kg} \text { fuel })^{-1}, \quad \mathrm{EF}_{\mathrm{NO}_{\mathrm{x}}} \sim 26 \pm$ $2 \mathrm{~g}(\mathrm{~kg} \quad \text { fuel })^{-1}, \quad \mathrm{EF}_{\mathrm{SO}_{2}} \sim 5.4 \pm 0.7 \mathrm{~g}(\mathrm{~kg} \text { fuel })^{-1}$, $\mathrm{EF}_{N_{\text {tot }}} \sim(1.38 \pm 0.2) \times 10^{16}$ particles $(\mathrm{kg} \text { fuel })^{-1}$, and $\mathrm{EF}_{\mathrm{PM}_{2.5}} \sim 2.81 \pm 0.30 \mathrm{~g}(\mathrm{~kg} \text { fuel })^{-1}$. The uncertainty covers errors from the instrumental uncertainties (Sect. 2.2), errors in calculating $\triangle \mathrm{CO}_{2}$ (since it was very sensitive to the background concentration), errors in the least squares slope determination, and errors in the assumptions in Eq. (4). Table 4 gives the average emission factors for all individual ships converted to NTP conditions. In Table 4 the ships are ordered according to the after-treatment systems. The ships equipped with the SCRs efficiently reduced the $\mathrm{NO}_{\mathrm{x}}$ emissions, and the ships utilising water in the after-treatment systems had high $\mathrm{PM}_{2.5}$ emissions. On the other hand, their $\mathrm{SO}_{2}$ emissions were smallest. One should remember that the emission factors vary from ship to ship and from moment 
Table 5. Estimated fuel sulphur contents along with standard deviations for all ships studied in this work. Also given is the information from the ship owners.

\begin{tabular}{lll}
\hline Ship & FSC (\%) & Owners' information \\
\hline A & $0.68 \pm 0.26$ & n.a. \\
B & $0.84 \pm 0.10$ & $<1.0 \%$ \\
C & $0.62 \pm 0.18$ & $<1.0 \%$ \\
D & $0.41 \pm 0.16$ & n.a. \\
E & $0.33 \pm 0.10$ & $<0.5 \%$ \\
F & $0.34 \pm 0.18$ & $<0.5 \%$ \\
G & $0.31 \pm 0.13$ & $<0.5 \%$ \\
H & $0.38 \pm 0.06$ & $<0.5 \%$ \\
I & $0.38 \pm 0.15$ & n.a. \\
J & $0.37 \pm 0.13$ & n.a. \\
K & $0.46 \pm 0.16$ & $<0.5 \%$ \\
\hline
\end{tabular}

n.a. - not available. (a)

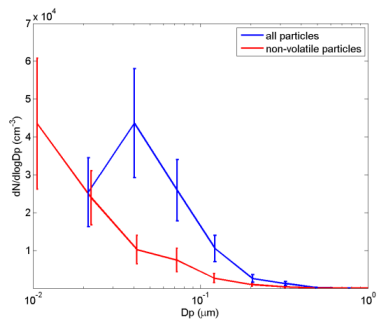

(b)

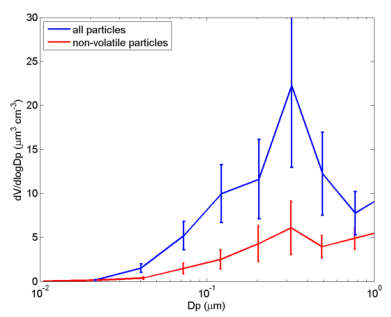

Fig. 9. Particle number (a) and volume (b) size distributions measured with the thermodenuder treatment (non-volatile particles) and without it (all particles) for ship $\mathrm{K}$ which had no after-treatment system. The error bars depict standard deviations.

to moment since they depend on many factors such as fuel, lubricant oil, after-treatment system, ship's speed, engine load, age of the ship etc.

In this work the emission factors are measured in the SECA areas after the reduction of the allowed FSC from $1.5 \%$ to $1 \%$. The obtained $\mathrm{EF}_{N_{\text {tot }}}$ are in the range of $(0.32-2.26) \times 10^{16}(\mathrm{~kg} \text { fuel })^{-1}$. In addition, regarding the SECA areas in 2010, Moldanová et al. (2013) report a low value of $0.5 \times 10^{16}(\mathrm{~kg} \text { fuel })^{-1}$ at $30 \%$ engine load, and Jonsson et al. (2011) values in the range of (1.373.6) $\times 10^{16}(\mathrm{~kg} \text { fuel })^{-1}$. On the other hand, Alföldy et al. (2013) who performed measurements in 2009 in the SECA area (FSC $<1.5 \%)$, report higher values of $(0.8-$ $5.7) \times 10^{16}\left(\mathrm{~kg}\right.$ fuel) ${ }^{-1}$. For higher FSC (from $2-5 \%$ ), number emission factors are typically higher, in the range of $(1.2-6.2) \times 10^{16}(\mathrm{~kg} \text { fuel })^{-1}$ (Chen et al., 2005; Sinha et al., 2003; Petzold et al., 2010). Unfortunately, the literature provides only a limited number of papers concerning $\mathrm{EF}_{N_{\mathrm{tot}}}$ for ships. Figure 8 and previous works (Fig. 13 by Alföldy et al., 2013) demonstrate that particle number emissions and FSC or $\mathrm{EF}_{\mathrm{SO}_{2}}$ are positively correlated. In spite of many variables affecting $\mathrm{EF}_{N_{\text {tot }}}$, the results discussed in this paper are an evident sign of the benefits of FSC reduction. (a)

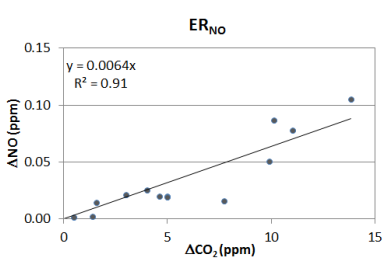

(c)

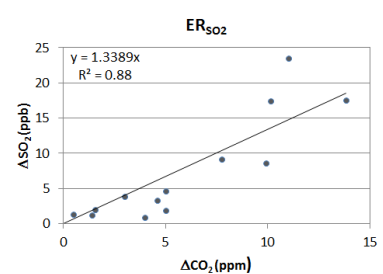

(b)

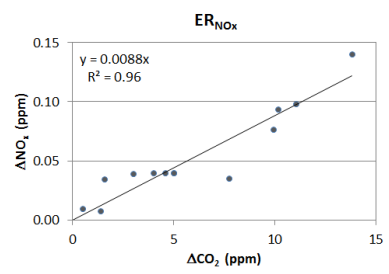

(d)

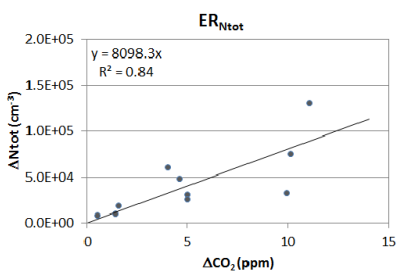

(e)

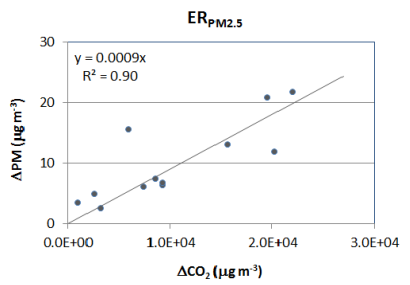

Fig. 10. Scatter plots of excess $\mathrm{NO}(\mathbf{a}), \mathrm{NO}_{\mathrm{x}}(\mathbf{b}), \mathrm{SO}_{2}(\mathbf{c}), N_{\text {tot }}(\mathbf{d})$, and $\mathrm{PM}_{2.5}$ (e) as a function of excess $\mathrm{CO}_{2}$ from ship $\mathrm{G}$. The units

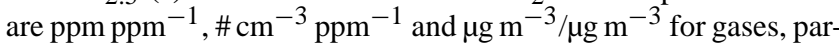
ticle number and mass concentration, respectively. Also shown are emission ratios (the slopes) and correlation coefficients.

\subsection{Fuel sulphur content}

An averaged fuel sulphur content (FSC; in \%) was estimated for each ship studied in this work (Table 5). We assumed that the individual ships used similar fuel each time. Based on the clear $\mathrm{SO}_{2}$ and $\mathrm{CO}_{2}$ peaks (Fig. 4), around 5-20 successful cases were found for each ship and the averaged FSCs were calculated. It should be noted that the measured fuel sulphur content is a weighted average of the main engine and auxiliary engine sulphur emissions. If both main and auxiliary engines use fuel with identical fuel sulphur content - as was the case for most of the ships in this study (Table 5) the measured value can be thought of as a direct indication of the fuel sulphur content used onboard the vessel. In the case where main and auxiliary engines use fuels with different sulphur content, the sulphur levels will be a combination of these contributions roughly equivalent to the ratio of main engine and auxiliary engine power used at the time of the measurement. In this case, the measured emission factors for $\mathrm{SO}_{2}$ and particles might be underestimated. Alföldy et al. (2013) estimated that the reduction of total $\mathrm{SO}_{2}$ emission factor caused by auxiliary engines' contribution can be $6 \%$ at sea and $30 \%$ in ports if FSC is $0.5 \%$ for MDO and $1.5 \%$ 
for HFO. As seen in Table 5, the measured FSCs do not exceed the values given by the ship owners, and for all ships they are less than $1 \%$, which was set as a limit in the Baltic Sea on 1 July 2010. However, none of them was below $0.1 \%$, which is the new directive by EU (European Union, 2012), coming into effect on 1 January 2015.

\section{Conclusions}

Particle and gaseous emissions from ship diesel engines with different after-treatment systems were measured by mobile laboratory in two different environments: inside the harbour areas in Helsinki, and along the narrow shipping channel near Turku, Finland. The particle number and volume size distributions, as well as the volatility properties of the particles, were investigated. Based on the measurements, the emission parameters and fuel sulphur contents for the 11 individual ROPAX ships were determined.

The results showed that the highest particle concentrations were $1.5 \times 10^{6}$ and $1.6 \times 10^{5} \mathrm{~cm}^{-3}$ in Helsinki and Turku, respectively, and the the particle number size distribution had two modes: the dominating mode peaked at $20-30 \mathrm{~nm}$, and the accumulation mode at $80-100 \mathrm{~nm}$. The majority of the particle mass was volatile, since, after heating the sample to $265^{\circ} \mathrm{C}$, the particle volume of the studied ship decreased by around $70 \%$. Simultaneously the modal diameters of the number size distribution shifted to $12 \mathrm{~nm}$ and $49 \mathrm{~nm}$, respectively.

The emission factors for $\mathrm{NO}_{\mathrm{x}}$ varied in the range of $25-100 \mathrm{~g}(\mathrm{~kg} \text { fuel })^{-1}$, for $\mathrm{SO}_{2}$ in the range of $2.5-17.0 \mathrm{~g}(\mathrm{~kg} \text { fuel })^{-1}$, for particle number between $(0.32-2.26) \times 10^{16} \#(\mathrm{~kg} \text { fuel })^{-1}$, and for $\mathrm{PM}_{2.5} 1.0$ $4.9 \mathrm{~g}(\mathrm{~kg} \text { fuel })^{-1}$. The ships equipped with SCR had the lowest $\mathrm{NO}_{\mathrm{x}}$ emissions, whereas the ships with DWI and HAM had the lowest $\mathrm{SO}_{2}$ emissions but the highest particulate emissions. For all ships the averaged FSCs were less than $1 \%$ but none of those was below $0.1 \%$ which will be the new EU directive starting on 1 January 2015. This will create large challenges for ship owners in the near future.

The global contribution from shipping particulate emissions is of the same order as the contribution from road traffic (Eyring et al., 2005). However, the shipping particulate emissions are only regulated through the sulphur level requirements and only poor estimates are available for nanoparticle exposure. Particle size distribution measurements are also needed in order to improve the quantification of indirect climatic effects of particles and $\mathrm{SO}_{2}$. Furthermore, this work might have relevance to city planning and appropriate locating of harbours.

Acknowledgements. The SNOOP project was financed by the Cental Baltic INTERREG IV A Programme 2007-2013 and the Centre for Economic Development, Transport and the Environment (ELY) of Southwest Finland. The authors are very grateful to
Mr. Aleksi Malinen at Metropolia University of Applied Sciences for his technical expertise and operation of Sniffer. We gratefully acknowledge the support of the member states of the Marine Environment Protection Committee of the Baltic Sea (Helcom) and the Finnish Transport Safety Agency. The research leading to these results has also received funding from the European Union's Seventh Framework Programme FP/2010-2013 within the TRANSPHORM project, grant agreement no. 243406.

Edited by: A. Richter

\section{References}

Agrawal, H., Welch, W. A., Miller, J. W., and Cocker, D. R.: Emission measurements form a crude oil tankder at sea, Environ. Sci. Technol., 42, 7098-7103, 2008.

Alföldy, B., Lööv, J. B., Lagler, F., Mellqvist, J., Berg, N., Beecken, J., Weststrate, H., Duyzer, J., Bencs, L., Horemans, B., Cavalli, F., Putaud, J.-P., Janssens-Maenhout, G., Csordás, A. P., Van Grieken, R., Borowiak, A., and Hjorth, J.: Measurements of air pollution emission factors for marine transportation in SECA, Atmos. Meas. Tech., 6, 1777-1791, doi:10.5194/amt-61777-2013, 2013.

Andreae, M. O. and Merlet, P.: Emission of trace gases and aerosols from biomass burning, Global Biogeochem. Cy., 15, 955-966, 2001.

Arnold, F., Pirjola, L., Aufmhoff, H., Schuck, T., Lähde, T., and Hämeri, K.: First gaseous sulphuric acid detection in automobile exhaust: Implications for volatile nano-particle formation and health risk, Atmos. Environ., 40, 7097-7105, 2006.

Ault, A. P., Moore, M. J., Furutani, H., and Prather, K. A.: Impact of emissions from the Los Angeles part region on San Diego air quality during regional transport events, Environ. Sci. Technol., 43, 3500-3506, 2009.

Berg, N., Mellqvist, J., Jalkanen, J.-P., and Balzani, J.: Ship emissions of $\mathrm{SO}_{2}$ and $\mathrm{NO}_{2}$ : DOAS measurements from airborne platforms, Atmos. Meas. Tech., 5, 1085-1098, doi:10.5194/amt-51085-2012, 2012.

Chen, G., Huey, L. G., Trainer, M., Nicks, D., Corbett, J., Ryerson, T., Parrish, D., Neuman, J. A., Nowak, J., Tanner, D., Holloway, J., Brock, C., Crawford, J., Olson, J. R., Sullivan, A., Weber, R., Schauffler, S., Donnelly, S., Atlas, E., Roberts, J., Flocke, F., Hübler, G., and Fehsenfeld, F.: An investigation of the chemistry of ship emission plumes during ITCT 2002, J. Geophys. Res., 110, D10S90, doi:10.1029/2004JD005236, 2005.

Corbett, J. J., Winebrake, J. J., Green, E. H., Kasibhatla, P., Eyring, V., and Lauer, A.: Mortality from ship emissions: A global assessment, Environ. Sci. Technol., 41, 8512-8518, 2007.

European Union: DIRECTIVE 2012/33/EU, available at: http://eur-lex.europa.eu/LexUriServ/LexUriServ.do?uri=OJ: L:2012:327:0001:0013:EN:PDF (last access: 20 January 2014), 2012.

Eyring, V., Köhler, H. W., van Aardenne, J., and Lauer, A.: Emissions from international shipping: 1 . The last 50 years, J. Geophys. Res., 110, D17305, doi:10.1029/2004JD005619, 2005.

Fridell, E., Steen, E., and Peterson, K.: Primary particles in ship emission, Atmos. Environ., 42, 1160-1168, 2008.

Fuglesvedt, J., Berntsen, T., Eyring, V., Isaksen, I., Lee, D. S., and Sausen, R.: Shipping emissions: From cooling to warming of cli- 
mate - and reducing impacts on health, Environ. Sci. Technol., 43, 9057-9062, 2009.

Healy, R. M., O’Connor, I. P., Hellebust, S., Allanic, A., Sodeau, J. R., and Wenger, J. C.: Characterisation of single particles from in-port ship emissions, Atmos. Environ., 43, 6408-6414, 2009.

IMO: International Maritime Organization: Regulations for the prevention of air pollution from ships and $\mathrm{NO}_{\mathrm{x}}$ technical code, Annex VI of the MARPOL convention 73/78 London, 1998.

Isakson, J., Persson, T. A., and Lindgren, E. S.: Identification and assessment of ship emissions and their effects in the harbour of Göteborg, Sweden, Atmos. Environ., 35, 3659-3666, 2001.

Jalkanen, J.-P., Johansson, L., Kukkonen, J., Brink, A., Kalli, J., and Stipa, T.: Extension of an assessment model of ship traffic exhaust emissions for particulate matter and carbon monoxide, Atmos. Chem. Phys., 12, 2641-2659, doi:10.5194/acp-12-26412012, 2012.

Jonsson, A. M., Westerlund, J., and Hallquist, M.: Size-resolved particle emission factors for individual ships, Geophys. Res. Lett., 38, L13809, doi:13810.11029/12011GL047672, 2011.

Juwono, A. M., Johnson, G. R., Mazheri, M., Morawska, L., Roux, F., and Kitchen, B.: Investigation of the airborne submicrometer partivcles emitted dredging vessels using a plume capture method, Atmos. Environ., 73, 112-123, 2013.

Kasper, A., Aufdenblatten, S., Forss, A., Mohr, M., and Burtscher, H.: Particulate emissions from a low-speed marine diesel engine, Aerosol Sci. Technol., 41, 24-32, 2007.

Keskinen, J., Pietarinen, K., and Lehtimäki, M.: Electrical low pressure impactor, J. Aerosol Sci., 23, 353-360, 1992.

Kumar, P., Ketzel, M., Vardoulakis, S., Pirjola, L., and Bitter, R.: Dynamics and dispersion modelling of nanoparticles from road traffic in the urban atmospheric environment - a review, J. Aerosol Sci., 42, 580-603, 2011.

Kumar, P., Pirjola, L., Ketzel, M., and Harrison, R.M.: Nanoparticle emissions from 11 non-vehicle exhaust sources - A review, Atmos. Environ., 67, 252-277, 2013.

Lack, D. A., Corbett, J. J., Onasch, T., Lerner, B., Massoli, P., Quinn, P. K., Bates, T. S., Covert, D. S., Coffman, D., Sierau, B., Herndon, S., Allan, J., Baynard, T., and Lovejoy, E. A.: Particulate emission from commercial shipping: Chemical, physical and optical properties, J. Geophys. Res., 114, D00F04, doi:10.1029/2008JD011300, 2009.

Lyyränen, J., Jokiniemi, J., Kauppinen, E. I., and Joutsensaari, J.: Aerosol characterisation in medium-speed diesel engines operating with heavy fuel oils, J. Aerosol Sci., 30, 771-784, 1999.

Malkki, M., Lounasheimo, J., Niemi, J., Myllynen, M., and Loukkola, K.: Air quality in the Helsinki Metropolitan Area in 2010, HSY publications 3/2011, 2011.

Malkki, M., Matilainen, L., Kousa A., Niemi, J., and Loukkola, K.: Air quality in the Helsinki Metropolitan Area in 2011, HSY publications 9/2012, 2012.

Marjamäki, M., Ntziachristos, L., Virtanen, A., Ristimäki, J., Keskinen,J., Moisio, M., Palonen, M., and Lappi, M.: Electrical Filter Stage for the ELPI, Society of Automotive Engineers (SAE) Technical Paper 2002-01-0055, 2002.

Moldanová, J., Fridell, E., Popovicheva, O., Demirdjian, B., Tishkova, V., Faccinetto, A., and Focsa, C.: Characterisation of particulate matter and gaseous emissions from a large ship diesel engine, Atmos. Environ., 43, 2632-2641, 2009.
Moldanová, J., Fridell, E., Winnes, H., Holmin-Fridell, S., Boman, J., Jedynska, A., Tishkova, V., Demirdjian, B., Joulie, S., Bladt, H., Ivleva, N. P., and Niessner, R.: Physical and chemical characterisation of PM emissions from two ships operating in European Emission Control Areas, Atmos. Meas. Tech. Discuss., 6, 39313982, doi:10.5194/amtd-6-3931-2013, 2013.

Molnár, P., Janhäll, S., and Hallquist, M.: Roadside measurements of fine and ultrafine particles at a major road north of Gothenberg, Atmos. Environ., 36, 4115-4123, 2002.

Morawska, L., He, C., Hitchins, J., Mengersen, K., and Gilbert, D.: Characteristics of particle number and mass concentrations in residential houses in Brisbane, Australia, Atmos. Environ., 37, 4195-4203, 2003.

Murphy, S. M., Agrawal, H., Sorooshian, A., Padroì, L. T., Gates, H., Hersey, S., Welch, W. A., Jung, H., Miller, J. W., Cocker, D. R., Nenes, A., Jonsson, H. H., Flagan, R. C., and Seinfeld, J. H.: Comprehensive simultaneous shipboard and airborne characterization of exhaust from a modern container ship at sea, Environ. Sci. Technol., 43, 4626-4640, 2009.

Petzold, A., Hasselbach, J., Lauer, P., Baumann, R., Franke, K., Gurk, C., Schlager, H., and Weingartner, E.: Experimental studies on particle emissions from cruising ship, their characteristic properties, transformation and atmospheric lifetime in the marine boundary layer, Atmos. Chem. Phys., 8, 2387-2403, doi:10.5194/acp-8-2387-2008, 2008.

Petzold, A., Weingartner, E., Hasselbach, J., Lauer, P., Kurok, C., and Fleischer, F.: Physical properties, chemical composition, and cloud forming potential of particulate emissions from a marine diesel engine at various load conditions, Environ. Sci. Technol., 44, 3800-3805, 2010.

Pirjola, L., Parviainen, H., Hussein, T., Valli, A., Hämeri, K., Aalto, P., Virtanen, A., Keskinen, J., Pakkanen, T., Mäkelä, T., and Hillamo, R.: "Sniffer" - a novel tool for chasing vehicles and measuring traffic pollutants, Atmos. Environ., 38, 3625-3635, 2004.

Pirjola, L., Paasonen, P., Pfeiffer, D., Hussein, T., Hämeri, K., Koskentalo, T., Virtanen, A., Rönkkö, T., Keskinen, J., Pakkanen, T. A., and Hillamo, R. E.: Dispersion of particles and trace gases nearby a city highway: mobile laboratory measurements in Finland, Atmos. Environ., 40, 867-879, 2006.

Pirjola, L., Lähde, T., Niemi, J. V., Kousa, A., Rönkkö, T., Karjalainen, P., Keskinen, J., Frey, A., and Hillamo, R.: Spatial and temporal characterization of traffic emission in urban microenvironments with a mobile laboratory, Atmos. Environ. 63, 156$167,2012$.

Rönkkö, T., Arffman, A., Karjalainen, P., Lähde, T., Heikkilä, J., Pirjola, L., Rothe, D., and Keskinen, J.: Diesel exhaust nanoparticle volatility studies by a new thermodenuder with low solid nanoparticle losses. Abstracts in the 15th ETH-Conference on Combustion Generated Nanoparticles, 26-29 June 2011, Zürich, Switzerland, 2011.

Saxe, H. and Larsen, T.: Air pollution from ships in three Danish ports, Atmos. Environ., 38, 4057-4067, 2004.

Schlager, H., Baumann, R., Lichtenstern, M., Petzold, A., Arnold, F., Speidel, M., Gurk, C., and Fisher, H.: Aircraft-based trace gas measurements in a primary European ship corridor. Proceedings of the International Conference on Transport, Atmosphere and Climate, Oxford, June 2006, TAC Extended Abstracts, 2007. 
Sinha, P., Hobbs, P. V., Yokelson, R. J., Christian, T. J., Kirchstetter, T. W., and Bruintjes, R.: Emissions of trace gases and particles from two ships in the southern Atlantic Ocean, Atmos. Environ., 37, 2139-2148, 2003.

Schlatter, J.: EURAMET Project 1027: Comparison of nanoparticle number concentration and size distribution. Federal Office of Metrology METAS, Lindenweg 50, 3084 Wabern, Switzerland, 29 January, 2010.

Turku: Turun kaupunkiseudun ilmanlaaturaportti vuonna 2011, available at: http://www.turku.fi/Public/default.aspx?nodeid= 12085, 2011 (abstract in English).

Virtanen, A., Rönkkö, T., Kannosto, J., Ristimäki, J., Mäkelä, J. M., Keskinen, J., Pakkanen, T., Hillamo, R., Pirjola, L., and Hämeri, $\mathrm{K}$.: Winter and summer time size distributions and densities of traffic-related aerosol particles at a busy highway in Helsinki, Atmos. Chem. Phys., 6, 2411-2421, doi:10.5194/acp-6-2411-2006, 2006.
Wehner, B., Birmili, W., Gnauk, T., and Wiedensohler, A.: Particle number size distribution in a street canyon and their transformation into the urban air background: measurements and a simple model study, Atmos. Environ., 36, 2215-2223, 2002.

Wierzbicka, A.: What are the characteristics of airborne particles that we are exposed to?, Doctoral thesis, Lund University, Department of Design Sciences, 2008.

Williams, E. J., Lerner, B. M., Murphy, P. C., Herndon, S. C. and Zahniser, M. S.: Emissions of $\mathrm{NO}_{\mathrm{x}}, \mathrm{SO}_{2}, \mathrm{CO}$ and $\mathrm{HCHO}$ from commercial marine shipping during Texas Air Quality Study (TexAQS) 2006, J. Geophys. Res., 114, D21306, doi:10.1029/2009JD012094, 2009.

Yli-Ojanperä, J., Kannosto, J., Marjamäki, M., and Keskinen, J.: Improving the nanoparticle resolution of the ELPI, Aerosol. Air Qual. Res., 10, 360-366, 2010. 